Click www.researchjournal.co.in/online/subdetail.html to purchase.

I

DOI: 10.15740/HAS/IJPS/11.2/383-385

Visit us - www.researchjournal.co.in

\title{
RESEARChNote
}

\section{A new addition to sheath blight of barnyard millet caused by Rhizoctonia solani}

\section{BIJENDER KUMAR}

Key Words : Small millet, Barnyard millet, Sheath blight, Rhizoctonia solani, Echinochloa frumentacea

How to cite this article : Kumar, Bijender (2016). A new addition to sheath blight of barnyard millet caused by Rhizoctonia solani. Internat. J. Plant Sci., 11 (2): 383-385, DOI: 10.15740/HAS/IJPS/11.2/383-385.

Article chronicle : Received : 06.01.2016; Accepted : 30.06.2016

$\mathrm{S}$ mall millet crops provide household food and nutritional security to millions of impoverished people inhabiting in remote and inhospitable areas. Due to their unique adaptability they are grown from sea level in Andhra Pradesh to $9000 \mathrm{~m}$ amsl of cold arid region of Jammu and Kashmir (Yadav et al., 2010). They belong to family Poaceae (Graminae) and are mostly cultivated as rainfed crops on marginal soils. Six small millets viz., finger millet, barnyard millet, foxtail millet, proso millet, kodo millet and little millet are the most important small millet crops of India. Among these, barnyard millet (Echinochloa frumentacea (Roxb.) Link) also called as Jhangora, Sawan or Madira (Hindi), has emerged as very important dual purpose feed and fodder crop. Barnyard millet is grown in many countries like India, China, Japan, Malaysia, East Indies, Africa and United States of America. In India, it is grown in Madhya Pradesh, Uttarakhand, Tamil Nadu, Andhra Pradesh, Karnataka, Maharashtra and Bihar. In Uttarakhand, it is grown over an area of about 0.64 lacs

\section{AUTHOR FOR CORRESPONDENCE}

BIJENDER KUMAR, Department of Plant Pathology, College of Agriculture, G.B. Pant University of Agriculture and Technology, Pantnagar, U.S. NAGAR (UTTARAKHAND) INDIA ha with annual production of 0.67 lacs tonnes (Anonymous, 2011) under rainfed conditions by small and marginal farmers in difficult conditions of cultivation at the mid-hill regions. Traditionally, the barnyard millet is used for the preparation of various products ranging from 'boiled Jhangora rice' to thick 'porridge'. Preparation of Jhangora rice along with curd and spices is called 'Chachera'. However, popping or puffing, Papad, Kachari and Sattu are the other uses of barnyard millet in Uttarakhand hills (Yadav et al., 2010). Its straw provides a good quality fodder for cattle, which is an important component of sustainable hill farming system, as fodder becomes scarce during winter. It is also used as feed for caged birds. In fact, the stover of barnyard millet is the best in terms of nutritional qualities among the existing cereal stovers.

Incidentally, barnyard millet is known to be affected by several diseases like; smuts, leaf blight, etc. (Parmeter and Whitney (1970). Recently, a new disease sheath blight caused by Rhizoctonia solani has also been reported by Kumar and Prasad (2009). Until 2012, the pathogen was known to produce symptoms on sheath. However, during 2012, in a routine survey for diseases of small millets in district Tehri-Garhwal, the classic blight symptoms were also observed on leaves of barnyard 